\title{
Larval performance in an estuarine crab, Chasmagnathus granulata, is a consequence of both larval and embryonic experience
}

\author{
Luis Giménez ${ }^{1,2,3, *}$, Klaus Anger ${ }^{2}$ \\ ${ }^{1}$ Sección Oceanología, Facultad de Ciencias, Iguá 4225, 11400 Montevideo, Uruguay \\ ${ }^{2}$ Biologische Anstalt Helgoland, Stiftung Alfred-Wegener-Institut für Polar- und Meeresforschung, 27498 Helgoland, Germany \\ ${ }^{3}$ Present address: Biologische Anstalt Helgoland, Stiftung Alfred-Wegener-Institut für Polar- und Meeresforschung, \\ 27498 Helgoland, Germany
}

\begin{abstract}
In an experimental laboratory investigation on an estuarine crab, Chasmagnathus granulata Dana, we investigated how salinities experienced during embryonic and larval development (embryonic and larval salinity exposures, respectively) and intraspecific variability of initial biomass at egg laying and hatching affected larval performance. The latter was measured in terms of survival rate, duration of development through successive stages, frequency of occurrence of an additional (fifth) zoeal stage, and size of the first juvenile instar. Ovigerous female crabs were maintained at 3 salinities $(15,20,32 \%)$. For each egg mass, biomass of freshly laid eggs and of freshly hatched larvae, respectively, was measured as dry mass, carbon, and nitrogen contents. After hatching, the larvae were reared at salinities of $5,10,15$, and $32 \%$. When larvae hatched from eggs that had been incubated at reduced salinities ( 15 or $20 \%$ ), their survival through the zoea I stage at low salinities (5 and $10 \%$ ) was high and stage duration was short. By contrast, poor survival and delayed development were observed in larvae reared at low salinities when they hatched from eggs that had been incubated in full-strength seawater $(32 \%$ ). Larval rearing in seawater allowed generally for highest survival and shortest development. While the embryonic salinity exposure had a strong influence on the performance of the first zoeal stage, later stages showed no significant response to the previous conditions of egg incubation. At advanced stages, low larval salinity exposure $(15 \%)$ led to consistently lower survival, longer duration of development, and higher proportion of larvae passing through an additional zoeal instar. However, larger juveniles metamorphosed from larvae that hatched from eggs incubated at low $(15 \%)$ salinity. The initial biomass of eggs and larvae, which varied significantly among broods produced by different females, was identified as another factor affecting larval performance. At constant $32 \%$, larvae with high initial biomass showed higher survival and faster development. Significantly more larvae developed through an additional instar when they hatched with a low initial biomass. In conclusion, our results show that the performance in a given phase of a complex life-history depends not only on the present environmental conditions but also on those prevailing in the preceding phase. Moreover, intraspecific variability in maternal energy investment into offspring production may play a significant role for the chances of larval survival and development in the plankton.
\end{abstract}

KEY WORDS: Larval ecology $\cdot$ Complex life cycle $\cdot$ Crustacean · Plasticity

Resale or republication not permitted without written consent of the publisher

\section{INTRODUCTION}

Marine invertebrates with a complex life cycle develop through a series of different phases including the embryonic, larval, and juvenile-adult periods. Classical marine ecological studies tended to consider each phase separately, attempting to explain the per- formance of an organism largely as a consequence of the present environmental conditions. In benthic ecology, for instance, changes in the abundance of benthic juveniles and adults have been chiefly related to changes in the benthic environment. However, the role of the environmental conditions experienced during the preceding larval phase in the plankton has increas- 
ingly been recognized as another important factor that may influence larval performance and thus, indirectly, also later life-history phases in the benthos (see discussion in Grosberg \& Levitan 1992). For example, barnacle settlement depends on larval supply (Gaines \& Roughgarden 1985), and this may be affected by the presence of predators (Gaines \& Roughgarden 1987) and by processes of larval transport in the pelagic environment (Roughgarden et al. 1988).

To ascertain how different phases within the life cycle are interdependent, numerous studies have recently analysed, under both field and laboratory conditions, the role of the larval phase for later juvenile survival (e.g. Pechenik et al. 1993, Eggleston \& Armstrong 1995, Qian \& Pechenik 1998, Gebauer et al. 1999). Laboratory experiments conducted under controlled conditions may be a particularly powerful tool for the evaluation of the significance of previous larval experience, for instance, late effects of delayed settlement and metamorphosis for subsequent juvenile performance (Pechenik et al. 1993, 1998, Qian \& Pechenik 1998, Gebauer et al. 1999).

For a better understanding of the ecology of species with complex life cycles, we therefore need to understand how the various life-history phases are linked to each other. One little known but potentially important link is that between the embryonic and larval phases. Effects of embryonic experience on larval performance may indirectly affect later post-settlement performance of juveniles. In marine decapod crustaceans, for example, initial larval size or biomass as well as larval development duration is influenced by temperature experienced during embryonic development (Kunisch \& Anger 1984, Shirley et al. 1987). Likewise, the salinity conditions during embryogenesis were observed to influence larval salinity tolerance and osmoregulatory capabilities in estuarine crabs (Rosenberg \& Costlow 1979, Laughlin \& French 1989, Charmantier et al. 2002), indicating processes of acclimatization or non-genetic adaptation (Kinne 1964a,b, 1971, Crisp \& Ritz 1967).

In the present investigation, we evaluated whether the salinity experienced during embryonic development as well as the initial larval biomass affected the larval performance in an estuarine crab, Chasmagnathus granulata Dana (Grapsoidea, Varunidae; for recent revision of grapsoid taxonomy see Schubart et al. 2002, and earlier papers cited therein). This species is very common and abundant in salt marshes and other estuarine and coastal zones of Brazil, Uruguay and Argentina (Boschi 1964, Spivak 1997). The adult crabs are physiologically well adapted to tolerate brackish and semi-terrestrial conditions (see Luquet et al. 2002, and earlier papers cited therein). Since no reproductive migrations occur in this species, egg lay- ing and embryonic development take place in brackish adult habitats, where typically wide salinity fluctuations occur (Spivak et al. 1994). Soon after hatching, however, the early larvae are transported by outflowing tidal currents to lower estuarine or coastal marine zones, where salinities are higher and more constant (Anger et al. 1994). The subsequent planktonic development comprises 4 (or exceptionally 5) zoeal stages, followed by the megalopa (Boschi et al. 1967, Pestana \& Ostrensky 1995). The megalopa returns to estuarine habitats, where it eventually settles and recruits to the benthic adult populations (Luppi et al. 2002).

As a consequence of this typical export strategy (cf. Strathmann 1982), the embryos and zoea I larvae of this species may experience wide salinity fluctuations, in particular, strongly reduced salt concentrations. Salinity has recently been shown to affect embryonic survival (Bas \& Spivak 2000) as well as the initial larval biomass (Giménez \& Anger 2001). In recent reports it was found that the salinity experienced during embryogenesis and the initial larval biomass affected (1) the survival and duration of zoea I develoment under food stress (Giménez 2002) or salinity stress (Charmatier et al. 2002), and (2) the accumulation of biomass from hatching to metamorphosis to the first juvenile instar under ad libitum food conditions and weak osmotic stress (Giménez \& Torres 2002). In the present paper, we evaluate how osmotic conditions experienced by embryos and larvae interact to affect larval performance under different scenarios of embryogenesis and larval retention or export.

Specifically we asked the following questions: (1) Does the osmotic experience during embryogenesis affect larval performance? (2) How do osmotic experiences during embryogenesis and larval development interact? (3) Do effects of osmotic experience differ among developmental stages? and (4) What is the role of the initial larval and egg biomasses and how do they interact with the osmotic experience in different developmental stages?

To produce different osmotic conditions during embryogenesis, we maintained ovigerous females at different salinities. Larvae obtained from these egg masses were reared also at different salinities to evaluate the effect of embryonic salinity exposure on larval salinity tolerance.

\section{MATERIALS AND METHODS}

Effects of embryonic and larval osmotic experience and those of initial egg and larval biomass on larval performance were evaluated in 2 different experiments. The first experiment was designed to evaluate exclusively the performance of zoea I larvae; in the 
(a) Experiment 1

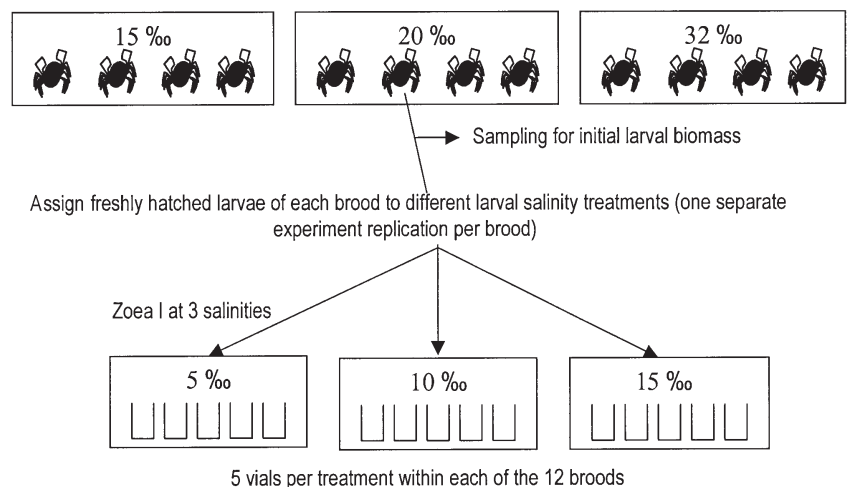

(b) Experiment 2

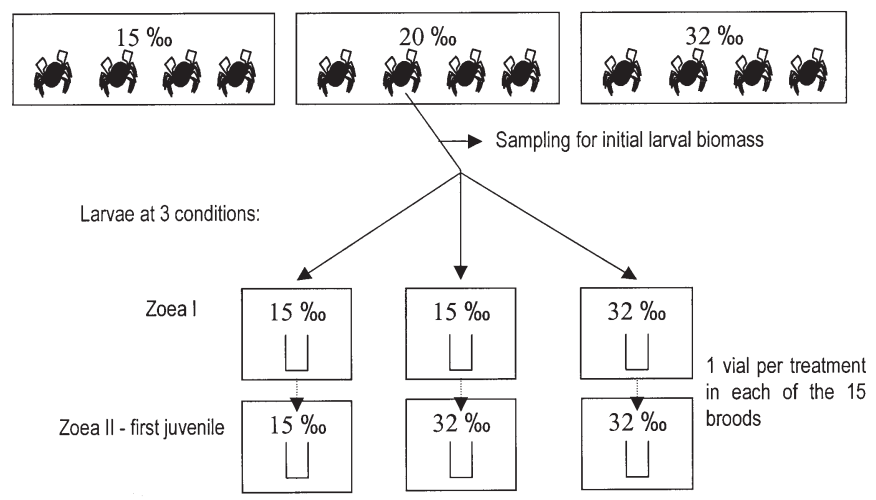

Fig. 1. Chasmagnathus granulata. Experimental design to study effects of embryonic and larval salinity exposures and initial larval biomass on larval development. (a) Expt 1: effects on performance of zoea $I_{i}(b)$ Expt 2: effects on performance of advanced stages

second experiment we evaluated the performance of advanced stages.

Expt 1. Performance of zoea I. Three groups of 4 ovigerous females each were isolated from egg laying until hatching and maintained at salinities of 15, 20 and $32 \%$, a temperature of $18^{\circ} \mathrm{C}$, and a photoperiod of 12:12 h light:dark (Fig. 1a). Previous to and after egg laying they were fed ad libitum with shrimp and isopods. Freshly hatched zoea I larvae of each brood were used either for determinations of initial larval biomass (see below) or to evaluate survival and duration of development under 3 larval salinity exposures $(5,10,15 \%)$. We did not use an acclimation period, since preliminary experiments showed that a period of 1 to $2 \mathrm{~d}$ at intermediate salinities (25 to $10 \%$ ) did not increase larval survival at $5 \%$, and we were not interested in exposing larvae to longer periods of decreasing salinity. For each salinity level we ran 5 replicate sets per brood consisting of 10 larvae each (Fig. 1a). All larvae were reared individually in $80 \mathrm{ml}$ vials at $18^{\circ} \mathrm{C}$ and a photoperiod of 12:12 h light:dark. In daily inter- vals, water was changed, the larvae were fed ad libitum with freshly hatched Artemia sp., and survival and moulting to the zoea II stage were recorded.

With this experimental design, we simulated egg production and embryonic development in different zones within an estuarine gradient. Theoretically, low pre-hatching salinities may cause either hypo-osmotic stress persisting from the embryonic through the early larval phase or acclimatization to reduced salinity. While the former effect should reduce the resistance of early larvae against low post-hatching salinities, the latter should enhance it. Besides embryonic and larval salinity exposure, also variability among broods was studied in this experiment, considering the initial biomass of eggs and larvae as additional factors potentially affecting early larval performance.

Statistical analyses for this and all other experiments were done following Day \& Quinn (1989), Sokal \& Rohlf (1995), Zar (1996) and Underwood (1997). Normality was checked with normal plots, and variance heterogeneity with Cochran's test (all variances were homogeneous, $\mathrm{p}>0.05$ ) unless otherwise specified. In order to evaluate the effects of salinity on larval survival we used a 3-way ANOVA whose factors were (1) embryonic salinity, (2) larval salinity exposure and (3) brood (4 levels), nested as a random factor within the factor embryonic salinity. Effects of initial biomass on survival and development duration were evaluated with Pearson's correlation coefficient.

Data of development duration were analysed with separated ANOVAs, since all larvae that hatched from $32 \%$ died after $1 \mathrm{~d}$ of exposure to $5 \%$. In the first 3 -way ANOVA (ANOVA-1), the factor larval salinity exposure included only the levels 10 and $15 \%$; all levels were included in the factors embryonic salinity exposure and brood. Raw and $\log (x+1)$-transformed data of this ANOVA were heterogeneous. We continued the analysis with transformed data since it showed the lowest level of variance heterogenity. The results of ANOVA-1 were compared with those of a simpler 2-way design (ANOVA-2), with embryonic and larval salinity exposure as factors, but ignoring the factor brood. While the latter design did not consider the variability among broods, it met the requirements of variance homogeneity. In ANOVA-2, we compared average durations of development obtained within each brood at each treatment combination. Both ANOVA-1 and ANOVA-2 gave the same results. Therefore, the statistics of ANOVA-1 were not misleading at least with regard to the embryonic and larval salinity exposures. Variance heterogeneity arose from the fact that zoea I larvae obtained from embryos incubated in full-strength seawater (32\%) and subsequently reared at $10 \%$ showed a high variability in duration of development. However, the shortest dura- 
tion of development registered in this treatment (8.0 d) was higher than the longest found in any other treatment $(7.5 \mathrm{~d})$ compared in ANOVA-1 and subsequent tests.

In another 3-way design (ANOVA-3), data from the $32 \%$ embryonic salinity exposure were excluded (no survival of larvae exposed to low salinities), so that the analysis included all factor levels for larval salinity, 2 factor levels for embryonic salinity (15 and 20\%), and 8 broods (instead of 12). The critical levels of the ANOVAs were changed to $\alpha=0.01$ to avoid an increase in type-I error to levels higher than 0.05 .

The effect of initial biomass on duration of development was evaluated with the Pearson correlation coefficient.

Expt 2. Performance at advanced stages. Three groups of 5 ovigerous females each were kept at 15, 20 and $32 \%$ respectively (Fig. $1 \mathrm{~b}$ ), as explained for Expt 1 . Freshly hatched larvae of each egg mass were either used for determination of initial larval biomass (see below) or randomly assigned to 3 larval salinity exposure conditions, consisting in rearing larvae (1) continually at $15 \%$, (2) at $15 \%$ during zoea I and at 32\% later; and (3) continually at $32 \%$. All experimental groups (with 50 individually maintained larvae each) were reared at these respective larval salinity exposures, until they reached the first juvenile stage or died. Zoeae were reared in $500 \mathrm{ml}$ vials; in the megalopa stage, a nylon gauze was given as an artificial substrate. After metamorphosis, carapace width of juvenile crabs was measured under a stereo microscope.

With this experimental design, we attempted to mimic several possible scenarios: (1) estuarine retention in brackish water, i.e. larval development taking place at a reduced salinity; (2) estuarine hatching and subsequent export to the sea, i.e. most of larval development outside the estuary; (3) all larval development under coastal marine conditions. As quantitative criteria of larval performance under these experimentally simulated scenarios, we recorded (1) the cumulative rate of survival, (2) the mean duration of development to successive developmental stages, (3) the proportions of larvae following either a short or a long developmental pathway (with 4 or 5 zoeal stages, respectively), and (4) carapace width in first-stage juveniles.

We used 3-way ANOVA with a covariate, whose factors were (1) embryonic salinity, (2) larval salinity exposure and (3) developmental stage. Developmental stage and larval salinity exposure were included as repeated-measures factors; the covariate was the initial larval biomass measured as carbon content at hatching. The effect of initial egg and larval biomass was evaluated as in Expt 1. ANOVAs were done with transformed data (arcsin for survival, logarithm for duration of development). The variances of the trans- formed data were homogeneous. For juvenile carapace width, we used a 2-way ANOVA with embryonic and larval salinity exposure as factors and untransformed data (variances were homogeneous and errors were normally distributed).

Determinations of initial egg and larval biomass. Immediately after egg laying and later after hatching, samples of eggs and larvae were removed to measure the initial biomass (dry weight, DW; carbon, $\mathrm{C}_{\text {; }}$ nitrogen, $\mathrm{N}_{\text {; }}$ sets of 5 replicates with 40 eggs or larvae each per brood) at the onset of embryonic and larval development respectively. All samples were rinsed for a few seconds in distilled water, blotted on filter paper, transferred to pre-weighed tin cartridges, freeze-dried for 24 to 48 h (GT2E Finn-Aqua Lyovac vacuum dryer), weighed (Mettler UMT2 microbalance) to the nearest $0.1 \mu \mathrm{g}$, and eventually analysed in a Carlo Erba EA 1108 Elemental Analyser.

\section{RESULTS}

\section{Performance of zoea I}

The osmotic conditions experienced by embryos affected the performance of zoea I, but this effect depended on the osmotic conditions experienced by larvae (there was a significant interaction between these factors: Table 1). Survival was generally lowest at the lowest larval salinity exposure $(5 \%)$, but the strength of this effect was modulated by the embryonic salinity exposure (Fig. 2a). Larvae originating from embryos that had been incubated in undiluted seawater (pre-hatching salinity $32 \%$ ) did not reach the zoea II stage at a larval salinity exposure of $5 \%$, and only $33 \%$ on average survived at $10 \%$. By contrast, zoea I survival was on average $>60 \%$ in all other treatments including the lowest larval salinity exposure (5\%o: Fig. 2a). In larvae reared at $15 \%$, survival was independent of the pre-hatching salinity.

Table 1. Chasmagnathus granulata. Three-way ANOVA on larval survival to zoea II. The factors were embryonic (E\%) and larval (L\%) salinity exposures, and brood nested in embryonic salinity exposure. dff: degrees of freedom of factor; MSf: mean square of factor; dfe: degrees of freedom of error; MSe: mean square of error. Significant effects are given in bold

\begin{tabular}{|lrrrrrc|}
\hline Factor & dff & MSf & dfe & MSe & $F$ & $p$ \\
\hline E\%o & 2 & 434.50 & 9 & 8.17 & 53.16 & $<\mathbf{1 0}^{-4}$ \\
L\%o & 2 & 256.82 & 18 & 5.11 & 50.22 & $<\mathbf{1 0}^{-7}$ \\
Brood & 9 & 8.17 & 144 & 1.07 & 7.66 & $<\mathbf{1 0}^{-\mathbf{8}}$ \\
Brood $\times$ L\%o & 4 & 83.01 & 18 & 5.11 & 16.23 & $<\mathbf{1 0}^{-5}$ \\
E\% $\times$ L\% & 18 & 5.11 & 144 & 1.07 & 4.79 & $<\mathbf{1 0}^{-7}$ \\
\hline
\end{tabular}



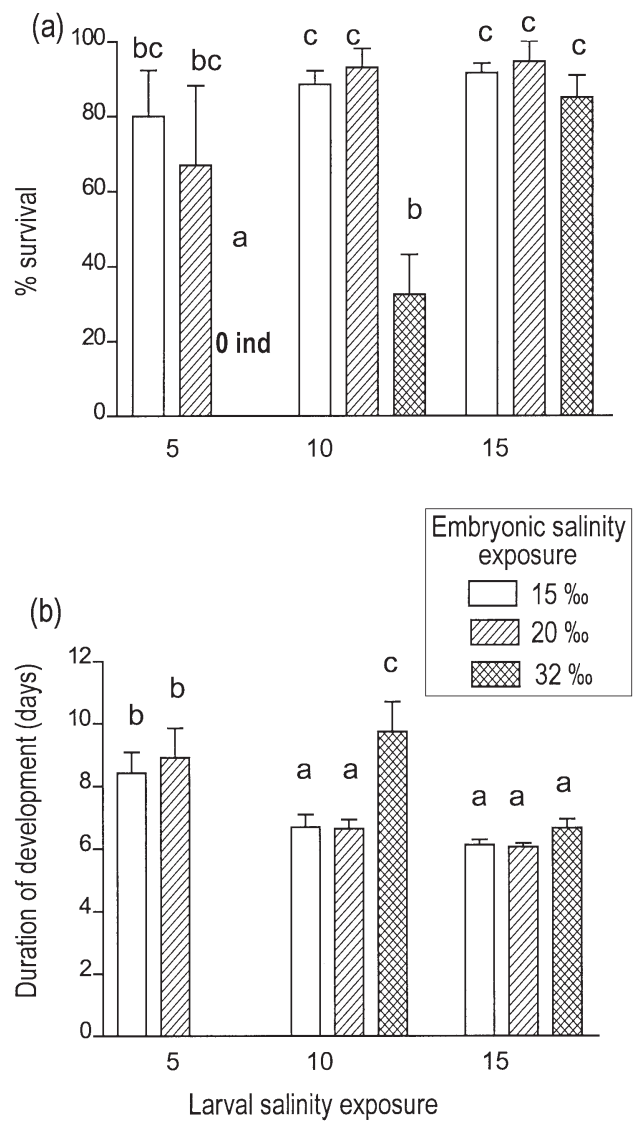

Fig. 2. Chasmagnathus granulata. (a) Percentage of survival and (b) duration of development to zoea II in zoea I larvae reared under different embryonic and larval salinity exposures. As all larvae that hatched from eggs at $32 \%$ died within the first day of exposure to $5 \%$, there is no data available on duration of development. Error bars: SD based on replicate broods. Different letters: significant differences $(p<0.05)$ among embryonic and larval salinity exposures reach the second stage (Fig. 2b); as a consequence of complete mortality in larvae obtained from embryos incubated in full-strength seawater (32\%) and subsequently reared at $5 \%$, no data on duration of development were obtained (Fig. 2b). ANOVA-3 (Table 2) showed that differences between the larval salinity treatment of 10 and $15 \%$ were statistically significant only when data from the embryonic salinity treatment of $32 \%$ were included in the analysis.

Possible relationships between survival of zoea I and initial larval biomass were studied separately for each factor combination, because both embryonic and larval salinity exposure affected significantly the rate of survival through the zoea I stage. At all tested salinities, the initial larval biomass did not affect larval performance. Correlation analyses showed no clear effect of initial biomass on either survival or duration of development of zoea I. Most relationships were insignificant, and statistically significant correlations were in some cases positive, but negative in others (Table 3).

\section{Performance in advanced stages}

Osmotic experience during embryogenesis did not affect larval performance in advanced stages when measured as survival or duration of development (Fig. 3, Table 4). While embryonic salinity exposure did not affect the proportion of zoea IV larvae that moulted to zoea V larvae $\left(F_{2,35}=0.57, \mathrm{p} \gg 0.05\right)$, it affected the duration of development to zoea $\mathrm{V}$ larvae $\left(F_{2,29}=15.33, \mathrm{p}<10^{-4}\right)$. For each treatment of larval salinity exposure, larvae that hatched from eggs incubated at $15 \%$ moulted to zoea $\mathrm{V}$ larvae in a shorter time than in other embryonic exposure treatments
Duration of development of the zoea I larvae was affected also by both embryonic and larval salinity exposures; moreover, there was a significant interaction between these 2 factors, as well as brood effects, as shown by ANOVA-1 (Table 2). The ANOVA-2 containing only the factors embryonic and larval salinity exposures revealed the same result regarding effects of salinity (embryonic salinity: $\mathrm{p}<10^{-6}$; larval salinity: $\mathrm{p}<10^{-5}$; interaction: $\mathrm{p}<$ $10^{-4}$ ). Duration of development at a larval salinity of $10 \%$ after an embryonic salinity of $32 \%$ was clearly longer than in all other treatments (Fig. 2b). Zoea I larvae reared at the lowest salinity (5\%) required, in general, the longest time to
Table 2. Chasmagnathus granulata. Three-way ANOVAs on duration of development to zoea II. Abbreviations and factors as in Table 1. No larvae from E\% = 32 survived to the zoea II at L\% $=5 \%$ : ANOVA- 1 evaluated effects without data from $\mathrm{L} \%$ o $=5 \%$; ANOVA-3 did the equivalent without data from $\mathrm{E} \%$ o $=32 \%$. Significant effects, at $\alpha<0.01$, are given in bold

\begin{tabular}{|c|c|c|c|c|c|c|c|}
\hline Treatment & Factor & dff & MSf & dfe & MSe & $F$ & $\mathrm{p}$ \\
\hline \multicolumn{8}{|l|}{ ANOVA-1 } \\
\hline $15,20,32$ & E\%o & 2 & 56.24 & 9 & 2.04 & 27.61 & $<10^{-3}$ \\
\hline 10,15 & L\%o & 1 & 58.71 & 9 & 0.57 & 102.40 & $<10^{-5}$ \\
\hline \multirow[t]{3}{*}{$1-12$} & Brood & 9 & 2.037 & 96 & 0.09 & 21.82 & $<10^{-6}$ \\
\hline & $\mathrm{E} \%$ o $\times \mathrm{L} \%$ о & 2 & 22.79 & 9 & 0.57 & 39.75 & $<10^{-4}$ \\
\hline & Brood $\times$ L\%o & 9 & 0.57 & 96 & 0.09 & 6.14 & $<10^{-6}$ \\
\hline \multicolumn{8}{|l|}{ ANOVA-3 } \\
\hline 15,20 & E\%o & 1 & 0.31 & 6 & 5.86 & 0.053 & 0.82 \\
\hline $5,10,15$ & L\%o & 2 & 62.77 & 12 & 0.89 & 70.25 & $<10^{-6}$ \\
\hline \multirow[t]{3}{*}{$1-8$} & Brood & 6 & 5.86 & 96 & 0.08 & 77.33 & $<10^{-6}$ \\
\hline & E\% × L \%о & 2 & 0.94 & 12 & 0.89 & 1.05 & 0.38 \\
\hline & Brood $\times$ L\%o & 12 & 0.89 & 96 & 0.08 & 11.80 & $<10^{-6}$ \\
\hline
\end{tabular}


(Fig. 4). Larvae obtained from an embryonic salinity of $15 \%$ tended to metamorphose to larger crabs than those from other embryonic salinities (Table 5); however, this effect was significant only when the data from larval salinity exposure $15 \%$ were included in the analysis $\left(F_{2,22}=4.65, \mathrm{p}<0.05\right)$.

In contast to embryonic salinities, larval salinity exposure significantly affected survival, duration of development (Fig. 3, Table 4), the proportion of zoea IV larvae moulting to zoea V larvae $\left(F_{2,35}=8.02, \mathrm{p}<\right.$ $10^{-3}$ ), and the duration of development to zoea V larvae
$\left(F_{2,29}=28.34, \mathrm{p}<10^{-6}\right)$. The lowest cumulative rate of survival and the longest duration of development to the megalopa and first juvenile stage were found when the larvae were reared continually at $15 \%$ (see Fig. 3). The effect of larval salinity exposure on survival and duration of development depended on the stage, with larger effects in advanced stages (Fig. 3). Continuous larval rearing in seawater $(32 \%)$ decreased significantly the proportion of zoea IV larvae that moulted to zoea V larvae and the total duration of development to zoea V stage (Fig. 4). Larvae reared at $32 \%$ took, on (a)

\section{Embryonic salinity exposures}

$15 \%$

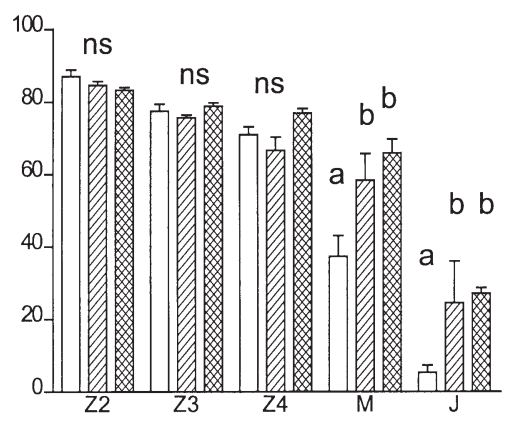

$20 \%$

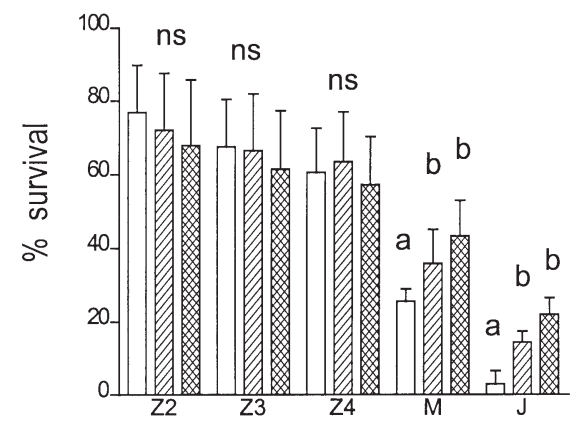

(b)
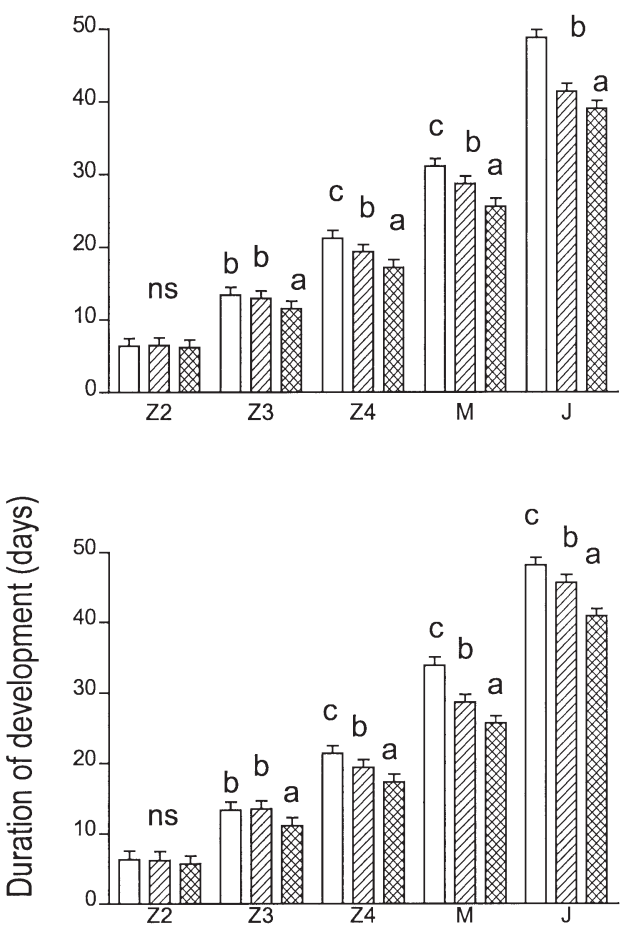
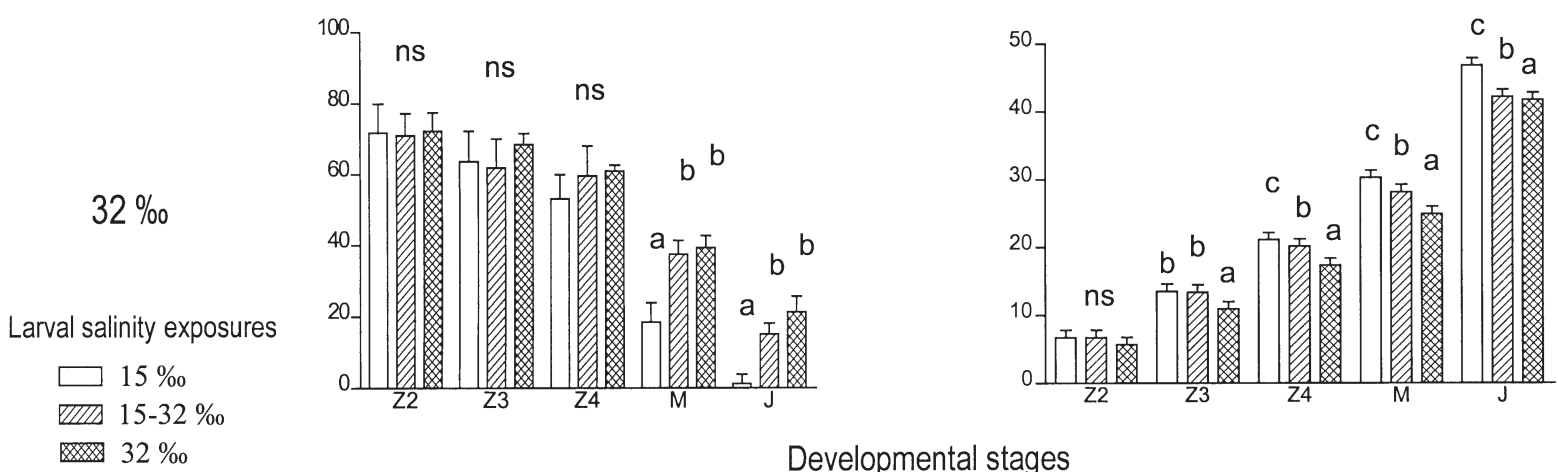

Developmental stages

Fig. 3. Chasmagnathus granulata. (a) Cumulative percentage of survival and (b) cumulative duration of development at different embryonic and larval salinity exposures. Z2: zoea II; Z3: zoea III; Z4: zoea IV; M: megalopa; J: first juvenile. Error bars: SD. Different letters: significant differences ( $<$ <.05) among different levels of the factor larval salinity exposure; ns: no significant differences 
average, $25 \mathrm{~d}$ to reach the zoea $\mathrm{V}$ stage, while those reared at $15 \%$ took about $30 \mathrm{~d}$. Neither larval salinity exposure nor its interaction with embryonic salinity

Table 3. Chasmagnathus granulata. Correlation coefficients between biomass measured as dry mass (DW), carbon (C), and nitrogen content $(\mathrm{N})$ of freshly hatched zoea I and survival to zoea II or duration of development of zoea I, for larvae reared at different embryonic $(\mathrm{E} \%)$ and larval (L\%) salinity exposures. Significant correlations $(p<0.05)$ are given in bold. nd: not determined

\begin{tabular}{|cccccccc|}
\hline \multirow{3}{*}{ E\% } & \multirow{4}{*}{ L\% } & \multicolumn{3}{c}{ Survival } & \multicolumn{4}{c|}{ Duration of development } \\
& & DW & C & N & DW & C & N \\
\hline 15 & 5 & 0.26 & $\mathbf{0 . 5 2}$ & 0.03 & -0.19 & 0.15 & 0.17 \\
15 & 10 & 0.01 & 0.20 & 0.06 & -0.31 & 0.01 & 0.03 \\
15 & 15 & 0.16 & 0.07 & 0.13 & -0.13 & 0.21 & -0.03 \\
20 & 5 & 0.06 & 0.09 & 0.22 & 0.36 & $\mathbf{0 . 4 4}$ & 0.27 \\
20 & 10 & $\mathbf{- 0 . 5 5}$ & $\mathbf{- 0 . 5 4}$ & $\mathbf{- 0 . 4 9}$ & $\mathbf{0 . 7 3}$ & $\mathbf{0 . 8 1}$ & $\mathbf{0 . 7 3}$ \\
20 & 15 & $\mathbf{- 0 . 4 8}$ & $\mathbf{- 0 . 4 6}$ & -0.43 & $\mathbf{0 . 7 9}$ & $\mathbf{0 . 8 8}$ & $\mathbf{0 . 8 2}$ \\
32 & 5 & nd & nd & nd & nd & nd & nd \\
32 & 10 & $\mathbf{0 . 7 0}$ & $\mathbf{0 . 5 1}$ & 0.25 & 0.01 & 0.26 & -0.04 \\
32 & 15 & 0.09 & 0.16 & 0.27 & -0.12 & $\mathbf{- 0 . 4 3}$ & $-\mathbf{0 . 4 9}$ \\
& & & & & & & \\
\hline
\end{tabular}
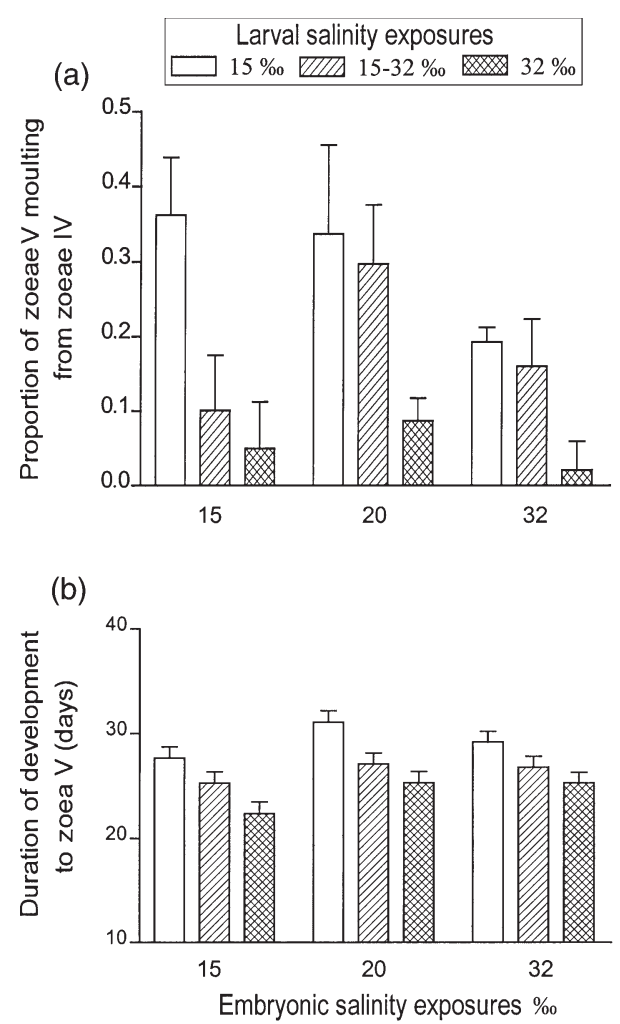

Fig. 4. Chasmagnathus granulata. (a) Proportion of zoea IV larvae moulted to zoea $\mathrm{V}$ larvae under different embryonic (E\%) and larval (L\%) salinity exposures. Significant effects were only for L\%: SNK test, $15=15-32>32$. (b) Cumulative duration of development to zoea V larvae. There were significant effects of embryonic and larval salinity exposures: SNK $(\mathrm{E} \%), 15<20=32$; SNK (L\%), $32<15-32<15$. Error bars: SD exposure affected significantly the size of the first juvenile instar $\left(F_{2,22}=0.18, F_{4,22}=2.10\right.$ respectively; both $\mathrm{p}>0.05)$. These patterns did not change when the

Table 4. Chasmagnathus granulata. Three-way ANOVA plus a covariate to evaluate effects of embryonic and larval salinity exposures and stage on larval survival and duration of development. Stage was included as a repeated-measures factor and the covariate was $\mathrm{C}$ content of freshly hatched zoea I. Abbreviations as in Table 1. Significant effects are given in bold

\begin{tabular}{|c|c|c|c|c|c|c|}
\hline Factor & dff & MSf & dfe & MSe & $F$ & $\mathrm{p}$ \\
\hline \multicolumn{7}{|l|}{ Survival } \\
\hline E\% & 2 & 583 & 11 & 975 & 0.60 & 0.56 \\
\hline Stage & 4 & 6145 & 48 & 64.45 & 95.34 & $<10^{-6}$ \\
\hline L\% & 2 & 329 & 24 & 56.69 & 5.82 & $<0.01$ \\
\hline $\mathrm{E} \%$ o $\times$ Stage & 8 & 29.03 & 48 & 64.45 & 0.45 & 0.88 \\
\hline $\mathrm{E} \%$ × L\%o & 4 & 23.97 & 24 & 56.69 & 0.42 & 0.79 \\
\hline Stage × L\%o & 8 & 141 & 96 & 14.29 & 9.88 & $<10^{-6}$ \\
\hline $\mathrm{E} \%$ $\times$ L\%o $\times$ Stage & 16 & 12.15 & 96 & 14.29 & 0.85 & 0.63 \\
\hline \multicolumn{7}{|c|}{ Duration of development } \\
\hline E\% & 2 & 4.63 & 4 & 8.39 & 0.55 & 0.61 \\
\hline Stage & 4 & 4983 & 20 & 1.21 & 4130 & $<10^{-6}$ \\
\hline L\%o & 2 & 135 & 10 & 3.04 & 44.43 & $10^{-5}$ \\
\hline $\mathrm{E} \%$ o $\times$ Stage & 8 & 1.58 & 20 & 1.21 & 1.31 & 0.29 \\
\hline $\mathrm{E} \%$ × L\%o & 4 & 3.29 & 10 & 3.04 & 1.08 & 0.42 \\
\hline Stage $\times$ L\%o & 8 & 20.52 & 40 & 1.29 & 15.93 & $<10^{-6}$ \\
\hline E\% $\times$ L\% $\times$ Stage & 16 & 2.23 & 40 & 1.29 & 1.73 & 0.08 \\
\hline
\end{tabular}

Table 5. Chasmagnathus granulata. Mean carapace width $(\mathrm{mm})$ of the first juvenile stage from different broods (letters) embryonic and larval salinity exposures. In parentheses: $\mathrm{SD}$ or indication of single values $(n=1)$

\begin{tabular}{|c|c|c|c|}
\hline $\begin{array}{l}\text { Embryonic } \\
\text { exposure }\end{array}$ & $\begin{array}{c}\text { Continuous } \\
15 \%\end{array}$ & $\begin{array}{c}\text { arval exposure } \\
15-32 \%\end{array}$ & $\begin{array}{c}\text { Continuous } \\
32 \%\end{array}$ \\
\hline \multicolumn{4}{|l|}{$15 \%$} \\
\hline A & $1.35(0.13)$ & $1.32(0.09)$ & $1.23(0.06)$ \\
\hline B & $1.34(0.09)$ & $1.30(0.04)$ & $1.31(0.09)$ \\
\hline $\mathrm{C}$ & & $1.23(0.05)$ & $1.26(0.05)$ \\
\hline D & & $1.25(0.04)$ & $1.26(\mathrm{n}=1)$ \\
\hline E & & $1.24(\mathrm{n}=1)$ & $1.22(\mathrm{n}=1)$ \\
\hline Mean & $1.34(0.003)$ & $1.27(0.04)$ & $1.26(0.03)$ \\
\hline \multicolumn{4}{|l|}{$20 \%$} \\
\hline $\mathrm{F}$ & $1.16(0.06)$ & $1.14(0.05)$ & $1.16(0.05)$ \\
\hline $\mathrm{G}$ & $1.20(0.06)$ & $1.25(0.07)$ & $1.16(0.08)$ \\
\hline $\mathrm{H}$ & & $1.36(\mathrm{n}=1)$ & $1.27(0.08)$ \\
\hline I & & $1.29(0.04)$ & $1.23(0.06)$ \\
\hline \multicolumn{4}{|l|}{$\mathrm{J}$} \\
\hline Mean & $1.18(0.03)$ & $1.26(0.09)$ & $1.20(0.06)$ \\
\hline \multicolumn{4}{|l|}{$32 \%$} \\
\hline K & $1.26(0.03)$ & $1.16(0.08)$ & $1.15(0.05)$ \\
\hline $\mathrm{L}$ & $1.20(\mathrm{n}=1)$ & $1.14(0.04)$ & $1.21(0.07)$ \\
\hline M & & $1.20(\mathrm{n}=1)$ & $1.38(0.19)$ \\
\hline $\mathrm{N}$ & & & $1.27(0.05)$ \\
\hline \multicolumn{4}{|l|}{$\mathrm{O}$} \\
\hline Mean & $1.23(0.04)$ & $1.17(0.03)$ & $1.25(0.10)$ \\
\hline
\end{tabular}


(a)
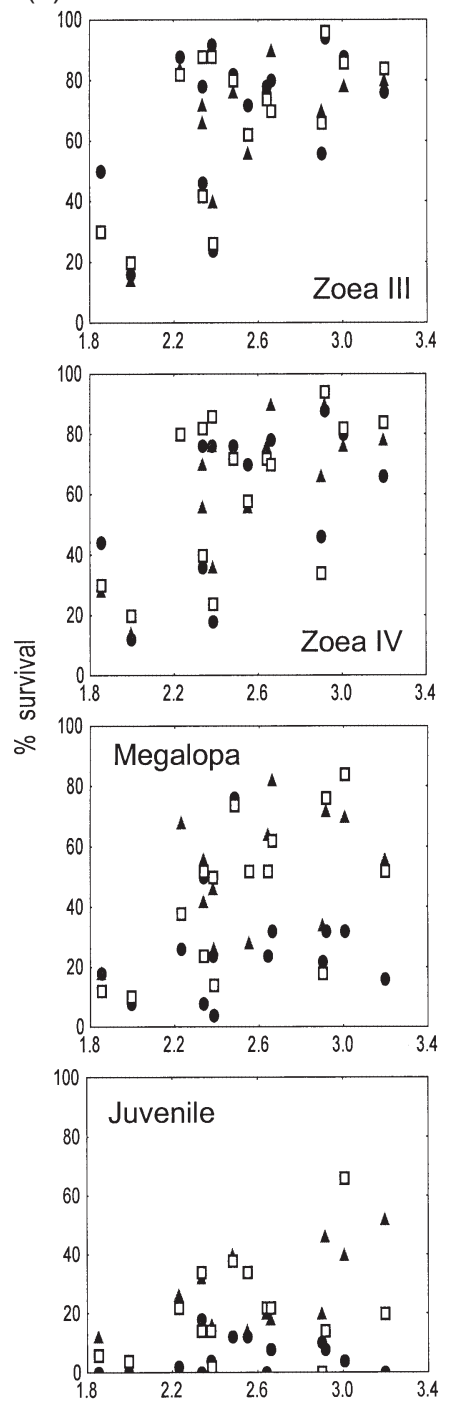

Carbon content of zoea I ( $\mu \mathrm{g} / \mathrm{ind})$

Fig. 5. Chasmagnathus granulata. Relationships between C content of newly hatched zoea I larvae and (a) cumulative survival or (b) cumulative duration of development to zoea III larvae, zoea IV larvae, megalopa and first juvenile

C content of freshly hatched zoea I larvae was included as a covariate in the ANOVA.

The initial egg and larval biomass affected larval performance, but its effect depended on the stage of development and the larval salinity exposure. Larval performance correlated better with initial larval biomass than with initial egg biomass. The best correlations were found when initial larval biomass was expressed as C content (Fig. 5) followed by correlations with DW and N content (not shown). Survival to the zoea II stage tended to increase with increasing initial biomass at hatching, reaching almost $100 \%$ at an intermediate biomass value and remaining nearly constant thereafter. Survival to the zoea III stage followed the same pattern (Fig. 5), but it was not significantly correlated with initial biomass for larvae reared at $15 \%$ (Fig. 6). In the subsequent stages, survival tended to increase with initial larval biomass, but the relationship was less clear (Fig. 5). For survival to the first juvenile stage, the correlation was significant only in larvae reared at $32 \%$ (Fig. 6a,b). Duration of development decreased with increasing initial larval biomass (Fig. 5). Negative correlations were significant until the megalopa stage, but later only at a larval salinity exposure of $32 \%$ (Fig. 6). At $15 \%$ there was a low range of variation in biomass (Fig. 5) because some hatches showed complete mortality in the megalopal stage, which partially removed the variability among broods.

The frequency of zoea IV larvae that moulted to the zoea $\mathrm{V}$ stage increased significantly with decreasing initial egg and larval biomass for larvae that were reared at $15 \%$ at least during the first zoeal instar (Fig. 7). Initial larval biomass did not significantly explain the size of the first juvenile instar from either larval salinity exposure $(r=0.39, p \gg 0.05$ for continuous rearing at $15 \% ; r=0.08, p \gg 0.05$ for $15-32 \% ; r=0.06 p \gg$ 0.05 for continuous rearing at $32 \%$ ). The size of the first juvenile did not significantly correlate with the proportion of zoea IV larvae moulting to the zoea $V$ stage $(r=0.13 ; p \gg 0.05)$.

\section{DISCUSSION}

During successive developmental phases of its complex life cycle, Chasmagnathus granulata may typically experience various salinity regimes. This is a consequence of ontogenetic migrations. Living in brackish coastal lagoons and in other estuarine environments, the benthic juvenile and adult crabs as well as the developing embryos experience highly variable, on average low, salinities. The early zoeae and, again, the megalopae may pass through strong salinity gradients when they are leaving from or returning to estuaries, respectively. This is in contrast to the late zoeal stages (zoea II through IV or V), which develop in coastal marine zones with on average higher and more stable salinities. Larval performance in the field may thus be affected by variations in salinity.

Our experimental observations of Chasmagnathus granulata have shown that, at least in the laboratory, larval performance may be affected by interacting effects of embryonic and larval salinity exposures and 


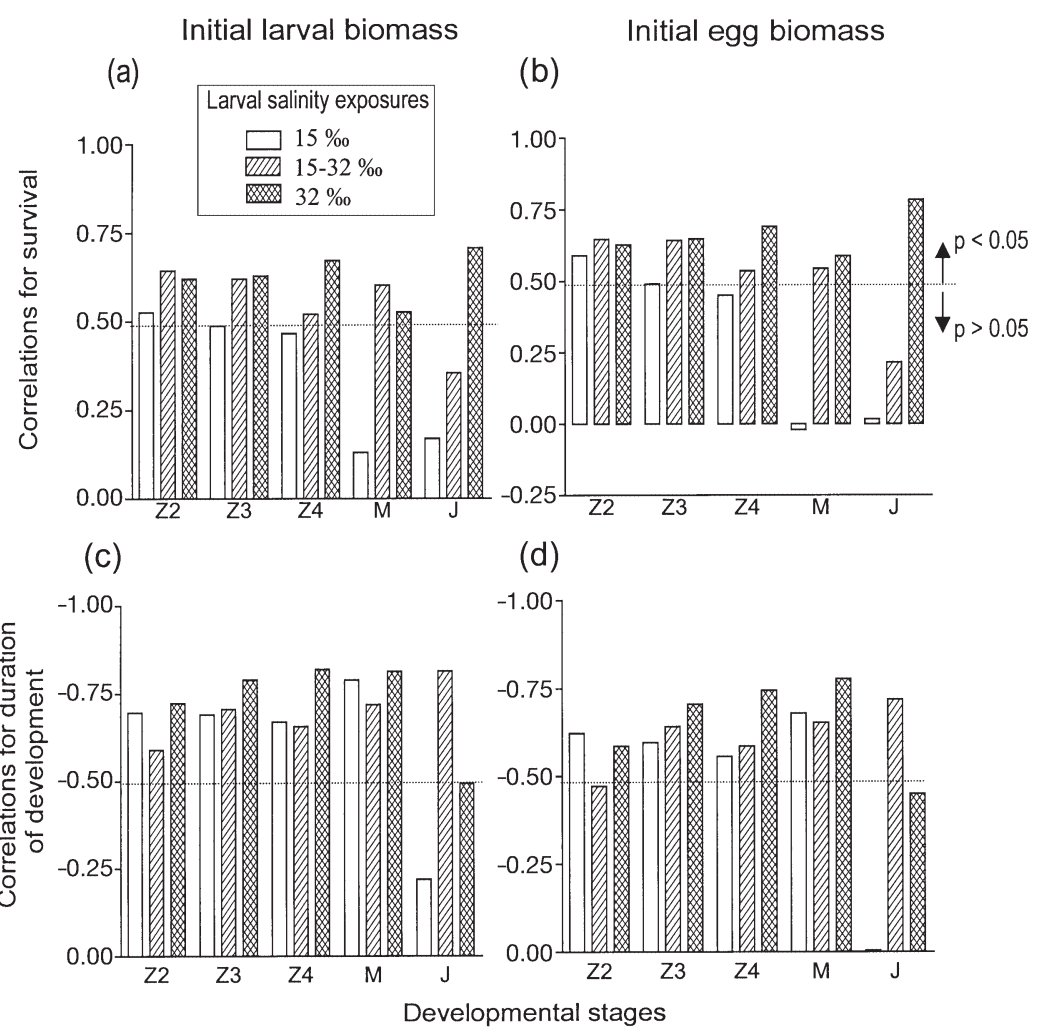

Fig. 6. Chasmagnathus granulata. Correlations between $\mathrm{C}$ content of $(\mathrm{a}, \mathrm{c})$ freshly hatched zoea I larvae and $(\mathrm{b}, \mathrm{d})$ freshly laid eggs with $(\mathrm{a}, \mathrm{b})$ cumulative survival and $(\mathrm{c}, \mathrm{d})$ cumulative duration of development, for 15 broods at different larval salinity exposures. Abbreviations for developmental stages as in Fig. 3

the intraspecifically variable initial biomass of eggs or larvae. As the initial larval biomass depends on the initial egg biomass and on the osmotic conditions experienced by embryos (Giménez \& Anger 2001), the effect of initial larval biomass on larval performance can be interpreted as a combined effect of osmotic conditions during embryogenesis and maternal factors. This suggests that patterns of recruitment and postsettlement success should depend not only on the environmental conditions prevailing during the periods of larval development and settlement, but also on those experienced during and before the embryonic phase.

\section{Effect of osmotic experience during embryogenesis on larval performance}

Osmotic conditions experienced during the embryonic phase affected the larval performance during the zoea I stage. Survival and duration of development through the zoea I stage at a reduced salinity (tested in Expt 1) are influenced by previous embryonic salinity exposure. Individuals incubated as embryos in sea- water (32\%) had subsequently a high larval mortality when they were exposed to low salinities (5 or $10 \%$ ). By contrast, those incubated as embryos at lower salinities (15 or $20 \%$ ) showed under the same posthatching conditions a fairly good performance. This acclimatization effect, which is associated with a significantly enhanced osmoregulatory capacity of the zoea I (Charmantier et al. 2002), was particularly important at an extremely low larval salinity exposure $(5 \%)$, where otherwise no survival beyond the first stage occurred. It may be argued that individuals from an embryonic salinity exposure of $32 \%$ may survive at $5 \%$ if they were exposed to gradual decrements in salinity at least during the first day after hatching. This may be a more realistic scenario than our experiments. However, ovigerous females of Chasmagnathus granulata do not migrate to the mouth of lagoons to release their larvae (Anger et al. 1994), so freshly hatched larvae may experience sudden changes in salinity. Preliminary experiments indicated that after a gradual decrease in salinity for about $1 \mathrm{~d}$, the subsequent survival of the larvae exposed to $5 \%$ was not enhanced. A more gradual decrease over a longer period would not be realistic, since the zoea I larvae are soon transported towards the open coast. A similar plastic response to salinity variation was observed in other estuarine crab species (Rhithropanopeus harrisiii, see Rosenberg \& Costlow 1979, Laughlin \& French 1989). Such a response should play an important role as a strategy for survival in physically unstable estuarine environments (Kinne 1964b, Spivak et al. 1994, Giménez 2003). Besides enhancing the resistance to salinity stress, previous acclimatization to stressful salinities may influence also the response to nutritional stress (Giménez 2002). These plastic response patterns are in contrast to those of stenohaline marine species, where continued hypoosmotic conditions cause cumulative stress effects including an increasing mortality in successive development stages (see e.g. Anger 1985, 1991, Qiu \& Qian 1999). Declining larval survival is associated with decreasing rates of lipid accumulation or, in very stenohaline species, with losses of lipid reserves (Torres et al. 2002).

An additional effect of embryonic salinity exposure is suggested for the size of the first juvenile crabs, as the largest crabs originated from treatments with low embryonic salinities. However, our ANOVAs may be 

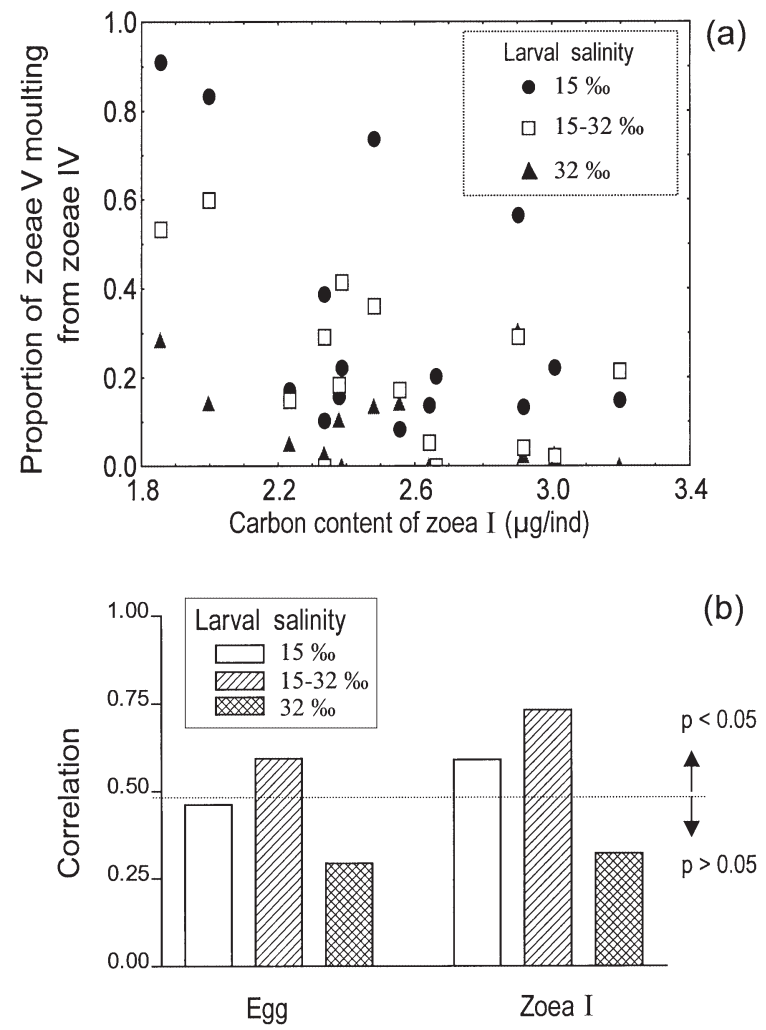

Fig. 7. Chasmagnathus granulata. Relationship between proportion of zoea IV larvae moulted to the zoea V stage and biomass of freshly hatched zoea I larvae and freshly laid eggs: (a) proportion of zoea V larvae vs C content of zoea I larvae; (b) correlations between proportion of zoea $\mathrm{V}$ larvae and $\mathrm{C}$ content at different larval salinity exposures

biased due to scarce data for certain factor combinations and low numbers of replicates. Larger juveniles at low salinities could be also a consequence of an increased proportion of juveniles metamorphosed from larvae that previously passed through 5 instead of 4 zoeal instars. These larvae, which were more frequently found at low salinities, metamorphose to larger megalopae (Giménez \& Torres 2002) and larger juveniles (L.G. unpubl. data). Lack of significant correlation between the proportion of larvae developing through a zoea V stage and juvenile body size may be due to the fact that at $15 \%$ complete mortality was in some broods observed in the megalopa stage.

\section{Stage-dependent effects of osmotic experience}

The osmotic experience during embryogenesis did not affect the survival or duration of development in advanced larval stages (tested in Expt 2). In the long term, the negative effects of low salinity on larval performance prevailed. This suggest that physiological plasticity in Chasmagnathus granulata may be limited to the early phase of larval development, which normally takes place in estuarine environments. The adaptability therefore declines in later zoeal stages, which develop in coastal marine waters with higher and more stable salinities. This pattern is consistent with ontogenetic changes in the osmoregulatory capacity, which is high at hatching but low throughout the subsequent zoeal stages (Charmantier et al. 2002). Adult C. granulata show again an acclimatory capacity (Cervino et al. 1996), consistent with their life in habitats with highly variable salinities (see Spivak et al. 1994). In conclusion, C. granulata exhibits ontogenetic changes in its acclimatory capacity, expressing it only in those stages which must face unpredictable physical conditions. The effectiveness of salinity acclimatization should primarily depend on the salinity conditions prevailing at the time and site of larval release. Anger et al. (1994), studying larval distribution in a coastal lagoon in Argentina, suggested that the zoea I larvae of C. granulata leave the estuary normally within 1 or a few days after larval release. However, larval transport to the sea may be interrupted when estuarine areas are temporarily isolated from the sea. When larval release takes place during such a period, previous acclimation should prolong larval survival under continued estuarine conditions, although high mortality should be expected within a few days.

Ontogenetic changes in the acclimatory ability should be responsible also for the stage-specific mortality caused by larval exposure to low salinity. During zoeal development at $15 \%$, mortality remained initially low and biomass accumulation remained unaffected (Torres et al. 2002), although hypo-osmotic stress affected larval morphology (deformed maxillipedes). Since the megalopa of Chasmagnathus granulata is a strong osmoregulator (Charmantier et al. 2002), it should be expected that this stage will show particularly high resistance to reduced salinities. However, in our experiments there was high mortality in the zoea IV larvae and megalopa reared at $15 \%$. This indicates cumulative effects of physiological stress occurring throughout the preceding zoeal development. This is consistent also with the assumption that mortality is particularly high when stress disturbs reconstruction processes associated with metamorphosis (Anger 1996).

Low larval salinity exposure $(15 \%)$ also increased the proportion of larvae that moulted to the zoea $\mathrm{V}$ stage. Ostrensky et al. (1997) reported that larvae developed more frequently through this additional instar when they were reared under nutritional stress. Thus, the development through an additional instar appears to be an unspecific response to environmental stress, which gives priority to survival over growth and morphogenetic development (cf. Knowlton 1974, Giménez \& Torres 2002). This flexibility (sensu Hadfield \& Strathmann 1996) should represent a strategy to 
cope with strong variability in environmental factors. As a consequence of an additional larval stage, a prolonged time in the plankton is expected. Sandifer \& Smith (1979) suggested that such variability in larval development may allow for a flexible response to unfavourable conditions, enhancing the chances for larval dispersal and transport to more favourable areas. In the natural plankton, however, pelagic predation pressure and other mortality risks (for review, see Morgan 1995) should select against an excessive lengthening of the larval phase, so these selective forces should constrain the evolution of extended larval dispersal and developmental variability.

\section{Effects of initial egg biomass and larval biomass}

Variability in survival and duration of development among larvae from different broods was related to initial biomass at egg laying and at larval hatching, showing effects of embryonic and maternal factors on larval performance. The highest correlations with biomass were found for carbon content at hatching, most likely because it is correlated with lipid content, the main fraction of reserves in decapod larvae (Anger 2001). In addition, in several other invertebrates, larval survival has been related to initial biomass of eggs or larvae, indicating that genetic or maternal factors are involved in the determination of larval fitness (Bayne et al. 1975, Kraeuter et al. 1982, Mashiko 1985, Bertram \& Strathmann 1998, Hancock 1998, Palacios et al. 1998, George 1999, Meidel et al. 1999). According to Hart (1995), potential costs of a reduction of biomass invested per offspring may imply (1) that larvae are small, with a low feeding rate and long duration of development; (2) prolonged predation pressure; or (3) that juveniles are smaller and more vulnerable to predation and other environmental stress. For Chasmagnathus granulata, the cost of reduction of egg and larval biomass implied lower survival and longer duration of development. Smaller larvae (in terms of biomass) hatched from smaller eggs (Giménez \& Anger 2001), and these showed a lower survival and longer duration of development not only under ad libitum feeding conditions (present study) but also when they were exposed to periods of starvation (Giménez 2002). Under weak osmotic stress, high initial biomass at hatching was associated with high levels of reserves in advanced zoeal stages (Giménez \& Torres 2002), most likely as a consequence of an enhanced ability of larger zoeae to capture and ingest prey (Pepin et al. 1992).

Under ad libitum feeding conditions, the effect of initial biomass on later survival and duration of development depended on the stage and on larval salinity exposure. At low rearing salinities (5 or $10 \%$ ), there was no consistent relationship between initial biomass and either larval survival or duration of development. At a moderately reduced salinity (15\%), the correlation between initial biomass and survival was significant in the zoea II larvae but not in later stages. Under continuous rearing in full-strength seawater (32\%o), in contrast, there were consistently higher rates of survival and shorter periods of development with increasing initial biomass. When development of the zoea I larvae took place at $15 \%$, but the subsequent stages were reared at $32 \%$, the correlation between survival and initial biomass was lost only in the megalopa stage. These patterns indicate that hypo-osmotic stress conditions generally exert a stronger influence than the brood-specific biomass of eggs and freshly hatched larvae, implying that the latter factor may play a significant role in explaining survival only when the site of larval release is located near the mouth of an estuary. Furthermore, it suggests that the individuals within an estuarine gradient are under differential selective pressures. While habitats with a very low or variable salinity regime should select for an enhanced physiological tolerance of hypo-osmotic stress, less stressful conditions may favour an enhanced investment of energy reserves per offspring. The fact that larvae are preferentially released during nocturnal ebb tides (Anger et al. 1994) perhaps reduces the need to 'bet' on the size of eggs and larvae. However, in Chasmagnathus granulata larval size is affected by salinity experienced by embryos, through an effect on the energy loss during embryogenesis (Giménez \& Anger 2001). Thus, to actually reduce the need to 'bet' on the size of larvae, females should exhibit some behaviour that reduces the variability in salinity experienced during embryogenesis. Such a possibility should be addressed in future studies.

Furthermore, the effects of initial biomass on the proportion of zoea IV larvae moulting to the zoea V stage depended also on the larval salinity exposure. Significant correlations were found when at least the zoea I larvae were reared at $15 \%$, but not when they were reared continuously at $32 \%$. This suggest that the site of larval release determines how well relatively smaller larvae will grow in subsequent stages, i.e. following a shorter or longer developmental pathway with differential durations of development.

\section{CONCLUDING REMARKS}

In the field, larval development of Chasmagnathus granulata should be a consequence of a complex interaction between past (i.e. maternal, embryonic) and present (larval) environmental conditions, including effects of parental energy investment per offspring, 


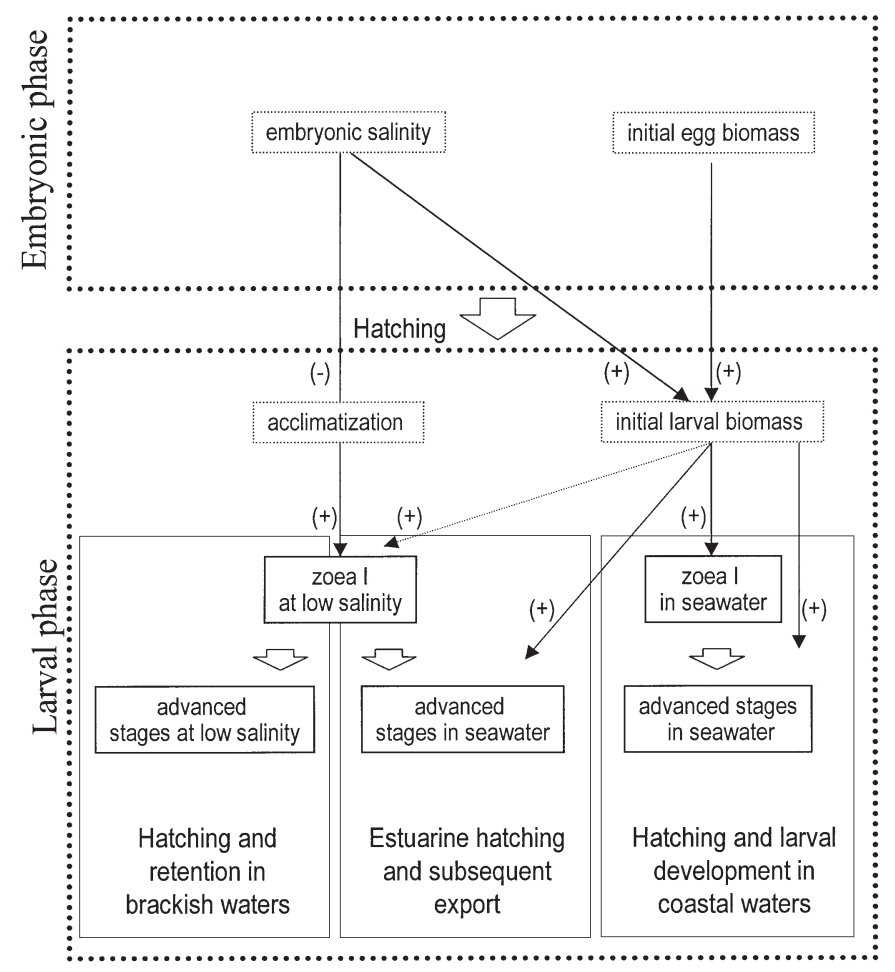

Fig. 8. Chasmagnathus granulata. Summary of effects of embryonic salinity exposure, initial egg biomass, and initial larval biomass on the performance (measured as survival or duration of development) of the zoea I larvae and advanced stages under different scenarios of larval development. The dotted arrow denotes a weak effect. The signs in parentheses show whether a relationship between 2 variables is positive or negative. For instance, initial larval biomass increases at higher embryonic salinities, while the acclimation to hypoosmotic stress decreases

larval salinity tolerance, and larval growth (Fig. 8). Embryonic exposure to low salinity may increase larval performance through an increment in the osmoregulatory capacity of the zoea I larvae, but on the other hand, it may also reduce the initial larval biomass. Estuarine retention of larvae is not favoured, since continued osmotic stress causes high mortality in advanced stages, independent of previous embryonic salinity exposure or initial larval biomass at hatching (Fig. 8). Estuarine hatching with subsequent export towards the sea, by contrast, is favoured, when the embryos have previously experienced low salinities. This embryonic condition enhances the acclimation to hypo-osmotic stress in the zoea I larvae, and thus increases their survival during the transitional period from hatching in estuarine habitats until transport to marine waters. Under this scenario, larval performance should increase with increasing initial biomass, i.e. with increasing female reproductive investment per offspring. Hatching and subsequent larval develop- ment in coastal marine waters is favoured only when embryos have been exposed to seawater. In this case, the initial larval biomass is particularly high due to lower embryonic energy losses under conditions of high salinity (Fig. 8). Future studies should further evaluate, also in other species, how the present performance during one (e.g. larval) life-history phase depends on the environmental experience of a previous (e.g. embryonic) phase, and how this may influence future (juvenile, adult) phases.

Acknowledgements. This work is part of the dissertation of L.G. We would like to thank C. Püschel for biomass measurements, K. Riesebeck for help with experiments and rearing Artemia. Special thanks to G. Torres, who helped with rearing larvae during the experiments and with taking samples for measurement of biomass. Financial support to L.G. was given by the Deutscher Akademischer Austauschdienst (DAAD) in Germany and Programa de Desarrollo de las Ciencias Básicas (PEDECIBA) in Uruguay.

\section{LITERATURE CITED}

Anger K (1985) Influence of salinity on larval development of the spider crab Hyas araneus reared in the laboratory. In: Gray J, Christiansen M (eds) Marine biology of polar regions and effects of stress on marine organisms. John Wiley \& Sons, Chichester, p 463-474

Anger K (1991) Effects of temperature and salinity on the larval development of the Chinese mitten crab Eriocheir sinensis (Decapoda, Grasidae). Mar Ecol Prog Ser 72: $103-110$

Anger K (1996) Salinity tolerance of the larval and first juveniles of a semiterrestrial grapsid crab, Armases miersii (Rathbun). J Exp Mar Biol Ecol 202:205-223

Anger K (2001) The biology of decapod crustacean larvae. Crustacean issues, Vol 14. Sweta \& Zeitlinger, Lisse

Anger K, Spivak E, Bas C, Ismael D, Luppi T (1994) Hatching rhythms and dispersion of decapod crustacean larvae in a brackish coastal lagoon in Argentina. Helgol Meeresunters 48:445-466

Bas C, Spivak E (2000) Effect of salinity on embryos of two south-western Atlantic estuarine grapsid crab species cultured in vitro. J Crustac Biol 20:647-656

Bayne B, Gabbott P, Widdows J (1975) Some effects of stress in the adult on the eggs and larvae of Mytilus edulis L. J Mar Biol Assoc UK 55:675-689

Bertram D, Strathmann R (1998) Effects of maternal and larval nutrition on growth and form of planktotrophic larvae. Ecology 79:315-327

Boschi E (1964) Los crustáceos decápodos Brachyura del litoral bonaerense (R. Argentina). Boln Inst Biol Mar 6: $1-100$

Boschi E, Scelzo M, Goldstein B (1967) Desarrollo larval de dos especies de crustáceos decápodos en el laboratorio. Pachyteles haigae Rodriguez Da Costa (Porcellanidae) y Chasmagnathus granulata Dana (Grapsidae). Bol Inst Biol Mar 12:3-46

Cervino C, Luquet C, Haut G, Rodríguez E (1996) Salinity preferences of the estuarine crab Chasmagnathus granulata Dana, 1851 after long-term acclimation to different salinities. Atlântica 18:69-75

Charmantier G, Giménez L, Charmantier-Daures M, Anger K 
(2002) Ontogeny of osmoregulation, physiological plasticity and larval export strategy in the grapsid crab Chasmagnathus granulata (Crustacea Decapoda). Mar Ecol Prog Ser 229:185-194

Crisp D, Ritz D (1967) Temperature acclimation in barnacles. J Exp Mar Biol Ecol 1:236-256

Day R, Quinn G (1989) Comparisons of treatments after an analysis of variance in ecology. Ecol Monogr 59:433-436

Eggleston D, Armstrong D (1995) Pre- and post-settlement determinants of estuarine dungeness crab recruitment. Ecol Monogr 65:193-216

Gaines S, Roughgarden J (1985) Larval settlement rate: a leading determinant of structure in an ecological community of the marine intertidal zone. Proc Natl Acad Sci USA 82:3707-3711

Gaines S, Roughgarden J (1987) Fish and offshore kelp forests affect recruitment to intertidal barnacle populations. Science 235:479-481

Gebauer P, Paschke K, Anger K (1999) Costs of delayed metamorphosis: reduced growth and survival in early juveniles of an estuarine grapsid crab, Chasmagnathus granulata. J Exp Mar Biol Ecol 238:271-281

George S (1999) Egg quality, larval growth, and phenotypic plasticity in a forcipulate seastar. J Exp Mar Biol Ecol 237: 203-224

Giménez L (2002) Effects of prehatching salinity and inital larval biomass on survival and duration of development in the Zoea 1 of the estuarine crab, Chasmagnathus granulata, under nutritional stress. J Exp Mar Biol Ecol 270: 93-110

Giménez L (2003) Potential effects of physiological plastic responses to salinity on population networks of the estuarine crab Chasmagnathus granulata. Helgol Mar Res (in press)

Giménez L, Anger K (2001) Relationships between initial egg and larval quality, and embryonic development at different salinities in the estuarine crab Chasmagnathus granulata. J Exp Mar Biol Ecol 260:241-257

Giménez L, Torres G (2002) Larval growth in the estuarine crab Chasmagnathus granulata: the importance of salinity experienced during embryonic development, and the initial larval biomass. Mar Biol 141:887-895

Grosberg R, Levitan D (1992) For adults only? Supply-side ecology and the history of the larval biology. Trends Ecol Evol 7:130-133

Hadfield M, Strathman M (1996) Variability, flexibility and plasticity in life histories of marine invertebrates. Oceanol Acta 19:323-334

Hancock M (1998) The relationship between egg size and embryonic and larval development in the freshwater shrimp Paratya australiensis Kemp (Decapoda: Atydae). Freshw Biol 39:715-723

Hart M (1995) What are the costs of small egg size for a marine invertebrate with feeding planktonic larvae? Am Nat 146:425-426

Kinne O (1964a) Non genetic adaptation to temperature and salinity. Helgol Meeresunters 9:433-458

Kinne O (1964b) Physiologische und ökologische Aspekte des Lebens in Ästuarien. Helgol Meeresunters 11:131-156

Kinne O (1971) Salinity. In: Kinne O (ed) A comprehensive, integrated treatise on life in oceans and coastal waters, Vol 1. Wiley, London, p 683-1244

Knowlton R (1974) Larval developmental processes and controlling factors in decapod Crustacea, with emphasis on Caridea. Thal Jugosl 10:139-158

Kraeuter J, Castagma M, van Dessel R (1982) Egg size and larval survival of Mercenaria mercenaria (L.) and Argopecten irradians (Lamark). J Exp Mar Biol Ecol 56:3-8
Kunisch M, Anger K (1984) Variation in development and growth rates of larval and juvenile spider crabs Hyas araneus reared in laboratory. Mar Ecol Prog Ser 15:293-301

Laughlin R, French W (1989) Interactions between temperature and salinity during brooding on subsequent zoeal development of the mud crab Rhithropanopeus harrisii. Mar Biol 102:377-386

Luppi T, Spivak E, Anger K, Valero J (2002) Patterns and processes of Chasmagnathus granulata and Cyrtograpsus angulatus (Brachyura: Grapsidae) recruitment in Mar Chiquita Lagoon, Argentina. Estuar Coast Shelf Sci 55: 287-297

Luquet C, Postel U, Halperin J, Urcola M, Marques R, Siebers D (2002) Transepithelial potential differences and $\mathrm{Na}^{+}$flux in isolated perfused gills of the crab Chasmagnathus granulata (Grapsidae) acclimated to hyper- and hypo-salinity. J Exp Biol 205:71-77

Mashiko K (1985) Comparison of survival and development between large and small neonates of a freshwater prawn under starvation conditions. Zool Sci 2:397-403

Meidel S, Scheibling R, Metaxas A (1999) Relative importance of parental and larval nutrition on larval development and metamorphosis of the sea urchin Strongylocentrotus droebachensis. J Exp Mar Biol Ecol 240:161-178

Morgan S (1995) Life and death in the plankton: larval mortality and adaptation. In: McEdward L (ed) Ecology of marine invertebrate larvae. CRC Press, New York, p 249-277

Ostrensky A, Pestana D, Sternheim U (1997) Effects of different diets on the larval development and ammonia excretion rates of the crab Chasmagnathus granulata Dana, 1851, under laboratory conditions. Cienc Cultura J Brazil Assoc Adv Sci 49:205-210

Palacios E, Ibarra A, Ramírez J, Portillo G, Racotta I (1998) Biochemical composition of eggs and nauplii in white Pacific shrimp, Penaeus vannamei (Boone), in relation to the physiological condition of spawners in a commercial hatchery. Aquacult Res 29:183-189

Pechenik J, Rittschoff D, Schmidt A (1993) Influence of delayed metamorphosis on survival and growth of juvenile barnacles Balanus amphitrite. Mar Biol 115:287-294

Pechenik J, Wendt D, Jarrett J (1998) Metamorphosis is not a new beginning. BioScience 48:901-910

Pepin P, Shears T, de Lafontaine Y (1992) Significance of body size to the interaction between larval fish (Mallotus villosus) and a vertebrate predator. Mar Ecol Prog Ser 81:1-12

Pestana D, Ostrensky A (1995) Occurrence of an alternative pathway in the larval development of the crab Chasmagnathus granulata Dana, 1851 under laboratory conditions. Hydrobiologia 306:33-40

Qian P, Pechenik J (1998) Effects of larval starvation and delayed metamorphosis on juvenile survival and growth of the tube-dwelling polychaete Hydroides elegans (Haswell). J Exp Mar Biol Ecol 227:169-185

Qiu J, Qian P (1999) Tolerance of the barnacle Balanus amphitrite amphitrite to salinity and temperature stress: effects of previous experience. Mar Ecol Prog Ser 188: $123-132$

Rosenberg R, Costlow J (1979) Delayed response to irreversible non-genetic adaptation to salinity in early development of the brachyuran crab Rhithropanopeus harrisii, and some notes on adaptation to temperature. Ophelia 18:7-112

Roughgarden J, Gaines S, Possingham H (1988) Recruitment dynamics in comlpex life cycles. Science 241:1460-1466

Sandifer P, Smith T (1979) Possible significance of variation in the larval development of palaemonid shrimp. J Exp Mar Biol Ecol 39:55-64 
Schubart C, Cuesta J, Felder D (2002) Glyptograpsidae, a new brachyuran family from Central America: larval and adult morphology of the Grapsoidea. J Crustac Biol 22: $28-44$

Shirley S, Shirley T, Rice S (1987) Latitudinal variation in the Dungeness crab Cancer magister: zoeal morphology explained by incubation temperature. Mar Biol 95:371-376

Sokal R, Rohlf F (1995) Biometry. Freeman and Company, New York

Spivak E (1997) Cangrejos estuaries del Atlántico sudoccidental $\left(25^{\circ}-41^{\circ} \mathrm{S}\right)$ (Crustacea: Decapoda: Brachyura). Invest Mar Valparaiso (Chile) 25:105-120

Spivak E, Anger K, Luppi T, Bas C, Ismael D (1994) Distribu-

Editorial responsibility: Otto Kinne (Editor),

Oldendorf/Luhe, Germany tion and habitat preferences of two grapsid crab species in mar Chiquita Lagoon (Province of Buenos Aires, Argentina). Helgol Meeresunters 48:59-78

Strathmann RR (1982) Selection for retention of export of larvae in estuaries. In: Kennedy VS (ed) Estuarine comparisons. Academic Press, New York, p 521-535

Torres G, Giménez L, Anger K (2002) Effects of reduced salinity on the biochemical composition (lipid, protein) of zoea I decapod crustacean larvae. J Exp Mar Biol Ecol 277: $43-60$

Underwood A (1997) Experiments in ecology. Cambridge University Press, Cambridge

Zar J (1996) Biostatistical analysis. Prentice-Hall, London

Submitted: July 18, 2001; Accepted: November 19, 2002

Proofs received from author(s): February 18, 2003 